\title{
THE GLOBAR WAR: THE EU'S APPLE TAX CASE
}

\author{
Jean-François Rougé \\ Agence Universitaire pour la Francophonie \& Ecole Supérieure de la Francophonie pour \\ l'Administration et le Management, Sofia, Bulgaria.
}

\section{ABSTRACT}

It is often said that globalization is just a new form of war between nations; an economic war. It is also a tax war; fiscal policies are a central point of the competition for territories' attractiveness (ROUGÉ et CHOPOV 2016). But the global tax war is not only another form of interstates conflict; it is also a brand new kind of war between global firms and state to share the burden of civil society. The aim of this paper is to clarify what is at stake in this war to be able to fight it.

Keywords: Tax systems, tax policies, tax havens, tax treaties, global firms, fiscal equity, fiscal incentives, harmful tax competition, rulings, fiscal lobbying, treaty shopping creative accounting.

The power to impose taxes is at the very center of the core conception of any kind of power (COLLIARD et MONTIALOUX 2007)(BRENNAN et BUCHANAN 1980). Through the history of civilizations, the only things that have changed are the persons who have the ability to impose taxes; the way taxes are defined and their amount(DOWELL 1965)(MARTINEZ et Alii 1989). Fiscal policies are always the result of fierce fight of power(AUMANN et KURZ 1977). Nevertheless, it's possible to say that the emergence of taxation is linked to the constitution of modern states. In fact, taxes are an integral part of the control of any territory":" In the tax area, a country may claim that all the income earn by a citizen or a company incorporated in that country is subject to taxation because of the legal connection to that country"(DOERNBERG 2001) By the way, fiscal policy is a true choice which shape deeply the kind of society in which we live.(GAFREY 2004) ${ }^{2}$

As long as business was mainly local and people did not move, the geographical link: the territoriality of taxation was not a problem. It began to be one with the huge growth of international trade in the $\mathrm{XIX}^{\circ 3}$. Then good and wealth began to move through the newly sat national borders. Then the brand new international institution: the Société des Nations sized the central question of double taxation that was considered as a brake on international trade expansion. Since, limitation of double taxation tanks to thousand of international treaties works properly and is no more the greatest problem of international tax law. Nowadays, what is at stake is the art, wealthiest individuals and corporations, put on escaping any taxation (MELOT 2004). For the brightest of them, the medium tax tare may be as low as $0,05 \%^{4}$ and the fiscal war between states and global firms seems to be officially declared: "Apple vs the EU is the biggest tax battle in history" title The Times of London".

As presented by states, things are clear: global firms are "the bad guy" and states,"the poor, powerless victims"! View from the position

\footnotetext{
${ }^{1}$ It is the reasonwhytaxlawismainlybased on the principle of territoriality.

2.That iswhy taxes are always sat the very center of everypoliticalcampaign for an election.

${ }^{3}$.As soon as 1927, Max LAMOUCHE wrote an Essay on the territoriality of taxes. Double taxation and taxevasion in international law.

4. It isspecially the fact of APPLE corp. In Ireland 2015: Source: CNN https://www.youtube.com/watch?v=7rwrAKOJFE4

5. http://time.com/4472500/apple-eu-irish-tax-bill/
} 
of global firms, they "always comply the law", if regulators are unhappy, "they have to begin by changing the law"! In fact, both of those affirmations are quite abusive. All began in the seventies when states began to deregulate. Multinational, then global corporations first used, then abused of this new freedom to optimize their tax bill. As long as they follow the law, it was; it is still, their right, even their duty according to FRIEDMAN (1970) for which "the social responsibility of business is to increase its profit" to escape undue taxation "so long at it stays within the rules of the game, which is to say, engage in open and free competition without deception and fraud'(FRIEDMAN 1970). But rules of the game have changed dramatically since the deregulations of the $70^{\prime 6}$. Nowadays states are weak; Politic vanishes (GÉNÉREUX 2008), and global firms are clever to escape or arrogant enough to refuse any kind of taxation(KERZNER et CHODIKOFF 2016). The war is declared". But that is not the all story. As the fiscal "cake" is reducing, states are rushing in a harmful tax competition to attract the biggest part of it. That is the way global tax war began. to any physical place or just past through physical territory without entering the legal territory and most of the value is based on rights (intellectual property), not on goods. States do not really know how to deal with this new reality. They still don't want to admit that they have to set global rules and global tax institutions to cope with global firms.

The result of this war is obvious; many global firms are wealthiest that most of the states $^{8}$, reducing drastically their freedom to the auto determination of their policies. Maybe still more dramatic Oxfam just reveal that the height (8) wealthiest persons of the world are richest that three milliards six hundred thousand (3 600000 000)of human beings (OXFAM 2017). This paper aims to understand the bases of this global tax war in order to help to create the weapons to fix it. It will first explain the guilty attitude of states, which allow, or even encourage the aggressive fiscal planning, they condemn. Once the game of states put in light, it will be possible to analyze the cynical game of global firms, which is threatening the stability of most of our societies(PIKETTY 2013)(J. STIGLITZ

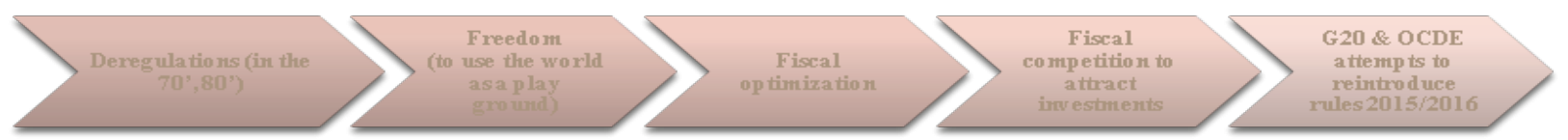

In practice, the situation is more complex, due to the dematerialization of most of the trade. Taxes used to be based on material wealth: land and real property first, then goods and shares. Even the taxation of work was quite simple in the industrialized world: it was chained to the territoriality of the machines or the offices. The huge spreading of information and communication technologies in the last 20 years changed the rules of the game. Today, many works are not linked to a defined territory; many transactions are not linked
2006); too many of them forgot that the ensure the smooth running of the society, the social cohesion is essential.(J. STIGLITZ 2003, 348)

\section{THE HYPOCRITICAL GAME OF THE STATES}

"L'économie à pour objet d'aller au delà des apparences. Elle est la lentille qui façonne le regard que nous portons sur le monde et nous permet de regarder au delà du miroir"

(TIROLE 2016, 20)

States spend a lot of energy to explain to their

\footnotetext{
6. Specifically, the (J. STIGLITZ 2016)deregulation of finance has been a destabilizing mistake (J. STIGLITZ 2003)

7. According to (GÉNÉREUX, 2008) Competitionisorganized to constitute a social activity. Competitioninducerules, which are accepted and respected by competitors, otherwise, itis not competition but war. Waris a rivalry, which allowseverymeans to win. (free translation, p31). This paperwilldemonstratethatmeansused in the fiscal game looks likethose of war, not of competition

${ }^{8}$ For a visual presentation of the facts (RENOU 2009)

${ }^{9}$ Free translation: The aim of economics is to go beyond appearances. It is the lenses, which form the way we are looking to the world, and allows us to look beyond the mirror.
} 
populations that they are doing everything they are able to do to fight fiscal optimization. They seem to defend offensively their power to tax, mainly since the great financial crash of 2008 deprive them of huge fiscal incomes and push them to spend great amount of money to preserve their bank and their social systems(JONES et TEMOURI 2016, 237). Each meeting of the OECD is, since that time, the time for them to reaffirm the importance of taxes and their willingness to enforce them without exemptions. In November 2012, G20's meeting unambiguously urges "the need to prevent (fiscal) base erosion and profit shifting". Unfortunately behind the strength of the affirmations, the reality is more nuanced. (GÉNÉREUX 2008); As says Jean TIROLE, we have to take a look beyond those appearances; on the other side of the mirror. There, in the "dark side of the mirror" things are less cute. If everybody agrees to tell that a fair society has to be based (also) on fair taxes (DREZET 2011), the reality is mostly that unfair taxes ${ }^{10}$ are creating a divided society at the border of the rupture. In practice, it seems that most of the states enter a fiscal competition to the bottom, to attract foreign direct investment or wealthy people. Where distinction between tax havens and harmful tax competition practiced by "virtuous" states used to be drawn (OECD, 1998, p. 20), the borders among those practices are entering a shadows area. Tax havens are violently condemned for a decade or so, butInvestments into offshore financial centers are at historically high levels and they account for an increasing share of the global FDI flows.(UNCTAD 2013) The following sections will try to explain that contradiction. It may be find in the fact that most tax havens have been created by great states to do what is otherwise incorrect to do: bargaining the sovereignty and openly breaking commonly accepted laws.

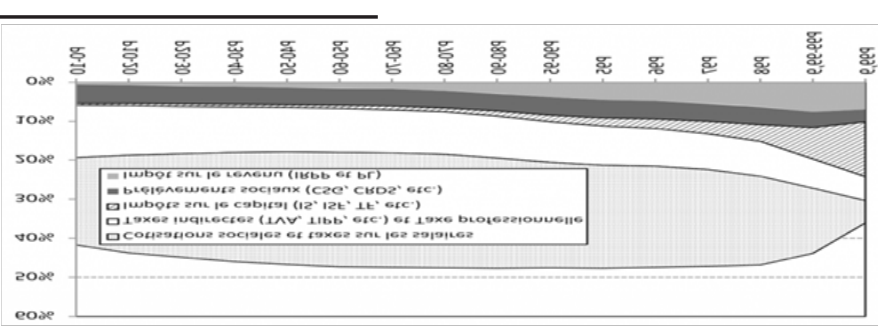

On the other hand, "virtuous states", mainly those of the OECD, which try to police international tax law, use to fight a (more or les hidden) fiscal war that may be described through two face: the "visible" war of the "harmful tax competition" and the war of the shadows consisting in manipulating fiscal or accounting law to bargain fiscal equity.

\section{"RENEGADE" STATES: THE FREEDOM TO BARGAIN SOVEREIGNTY}

Even if bargaining of sovereignty is not the exclusive privilege of tax havens ${ }^{11}$,it is their trademark (ZUCMAN 2013). Bargaining of sovereignty consist mainly in changing the natural law that may apply to something or somebody. That's quite simple due to the freedom of movement, transactions and people, which apply since the 1970'. Often abusing of this freedom, juridical operations are placed under the law of complaisant states only in order to offset the constraints of the original regulation. That's the reason why one also calls them "renegade" states (EDEN et KUDRLE 2005) that SITGLITZ (2016) qualify of “dark side of globalization". Tax havens are accused, not without very good reasons, to the scourge of the age. To sum up, one may reproached them: to dry out the fiscal base of the "virtuous states"(PALAN, MARPHY et CHAVAGNEUX 2009); to be deprived of any kind of morality (PERROT 2016); to practice money laundering on large scale (MIHU 2012)(PEILLON 2004)...; and last, but not least, to have been a major cause of the financial crisis of 2008 and made it worse(PICCIOTTO 2009). All that has been extensively analyzed, and will not holds our attention here. The point that will be insisted on is that tax heavens have largely been

${ }^{10}$ (DELSOL, L'injustice fiscale ou l'abus de bien commun 2016). Fr: Prélèvements obligatoires sur les revenus primaires en 2010, Source: TAXIPP 0.1. (BOZIO, et al. 2012)

${ }^{11}$ For example, in 2011, Great Britain changed its tax law to attract wealthy people. When it used to take five years to obtain the status of permanent resident and its huge tax advantages for foreigners, the delay has been shortened to three yeas for people who will come in England with at least three million pounds; and to two years for the owners of more than ten million pounds (CHAVAGNEUX 2011) or Italy 2017 (DUMONT 2017) 
created by "virtuous" states to do things in a way that greatness and honorability reprove! Then it will be possible to analyze the main tools they offer to circumvent taxation.

\section{"RENEGADE" STATES: AN ART TO ESCAPE TO THE DUTY OFVIRTUE}

Whatever democratic or monarchic, the core principle of great nations is virtueand the principle of monarchies is honor. (SIMONNOT 1998, 68).

Then, integrity, or at least an image of integrity, is priceless for them. That prohibits them to do openly many things what moral could reprove. By the way, it highlights the importance of the competition between law systems (J. ROUGÉ 2013): common law, which "generating loopholes that were used to develop taw havens", and Civil law reputed (wrongly) as less "business" friendly ${ }^{12}$ (PALAN, MARPHY et CHAVAGNEUX 2009). The problem began when necessity or greed urge them to do what they should not! Far from being purely philosophical, those principles may explain why great states invented tax havens; United Kingdom first during the $\mathrm{XIX}^{\circ}$ century $^{13}$ (MARA 2015). Since, they have prospered without cutting their close links with their motherland ${ }^{14}$. " $A$ tax haven which is a dependency benefits at no cost to itself from the diplomatic, financial and other infrastructure provisions provided by the home country"'15 (OECD, 1998, p. 25). That maybe explain why there are almost no poorly governed tax havens(DHARMAPALA et HINES 2006) . For the matter, how to imagine people foolish enough to invest money or rights of property, where they may be at state, like in so many corrupt countries thought the world. So governance quality "exert at least as powerful an effect on tax havens status" until being a casualty of this statute(DHARMAPALA et HINES 2006).

In practice, tax havens serve three main purposesmorally difficult to follow in "virtuous states": They provide a location for holding passive investments ("money boxes"); They provide a location where "paper" profits can be booked; and they enable the affairs of taxpayers, particularly their bank accounts, to be effectively shielded from scrutiny by tax authorities of other countries ${ }^{16}$.(OECD, 1998, p. 22) The geographical proximity of most of tax havens from the main trade and financial centers of the world is there to confirm the close links between "virtuous and renegade" states. And at the question "why do offshore tax havens still exist?" posed by the BBC on 30 July $2015^{17}$; the best response is probably that "no major state" really wants them to be eradicated ... maybe due to their mastering in the art of grey. them to be eradicated ${ }^{18} \ldots$ maybe due to their mastering in the art of grey.

\section{"RENEGADE" STATES: AN ART OF GREY}

In spite their virtuous affirmations, questioning the true position of big states aboutthe question of tax heavens ${ }^{19}$ is a duty: big states seem schizophrenic; in one hand they condemn them violently, mainly at the end of each G20 comities since 2009,

\footnotetext{
${ }^{2}$ Even if Switzerland and the Netherlands, both CMEs, have a civil law system and are arguably tax havens themselves. It is well known that the latter is an attractive destination for some German MNEs (JONES et TEMOURI 2016, 241)

${ }^{13}$ The preeminent role of UK in the birth and development of tax havensinclude the size of the British Empire and its central role in the industria revolution; the dominance of commercial and financial elites positioned in the City of London; the development of the Euromarket in the 1950s; and finally the widespread use of common versus civil law in the United Kingdom and across its colonial outposts. (PALAN, MARPHY et CHAVAGNEUX 2009)

${ }^{14}$ Seven out of the UKs fourteen overseas territories can be regarded as tax havens: Bermuda, Cayman Islands, British Virgin Islands, Gibraltar, Turks and Caicos, Anguilla and Montserrat. But in addition to these locations, it is also important to consider the Crown Dependencies of Jersey, Guernsey and the Isle of Man and the former colony of Hong Kong. (PALAN, MARPHY et CHAVAGNEUX 2009)

${ }^{15}$ The authors precise that « tax havens score very well on cross-country measure of governance quality that include measure of voice an accountability, political stability, governance effectiveness, rule of law and control of corruption

${ }^{16}$ The lack of effective exchange of information is one of the key factors in identifying a tax haven since it limits the access by tax authorities to the information required for the correct and timely application of tax laws. (OECD, 1998)

${ }^{17} \mathrm{http}: / / \mathrm{www} . \mathrm{bbc} . \mathrm{com} / \mathrm{news} / \mathrm{business}-33628020$

In the next part of this study, the responsibility of states regarding to this lack of willingness will be explained and nuanced.

${ }^{18}$ In the next part of this study, the responsibility of states regarding to this lack of willingness will be explained and nuanced.

${ }^{19} \mathrm{OECD}$ : it has identified four key features which make a country a tax haven: "no or low taxes, lack of effective exchange of information, lack of transparency, and no requirement of substantial activity" and set up an official list
} 
in the other hand they use them indecently! It is not important to stress here the attacks that G20' nations strikes against renegade states at the end of each meeting; it is largely documented in the press or through the publications of OECD. More interesting is to put in light the fact that those same nations at least tolerate tax heavens, or worst use them.

The first argument is logically implacable. Financial giants, tax havens are economical and political dwarfs. There is no way for such territories to be able to ignore the commune willingness great states, mainly the one of United States and European Union; their worst (auto proclaimed) enemies(ZUCMAN 2013). As a matter of facts, when the UnitedStates want to impose their law, they use to do it; whatever the questionability, or even the doubtfulness of the legality, in from of the (commonly accepted) international law, of the legal procedure they use to reach their aim. an indirect use of tax heavens by state owed firms. For example, Le Figaro, one of the leading newspapers in France reported that Electricité De France (EDF), owned à 84\% by the French State, seems to use three tax heavens to localize its profits (GOLLA 2014). How is-it possible for a White Knight of the war against aggressive tax planning and tax heaven to do that? May we consider that there are two weights, two measures; one for the states; one for their citizen? That will be unacceptable in democracies! ... So, here again, the best explanation is that official condemnation of tax heaven may be more a principle that a real willingness. This argument is reinforced by the fact that leading firms of big states, hugely use tax heavens in their activities; first of all, the one in the banking and finance industry. It is so strange to see bank breaking ethic regulation be severely sanctioned, when the same banks

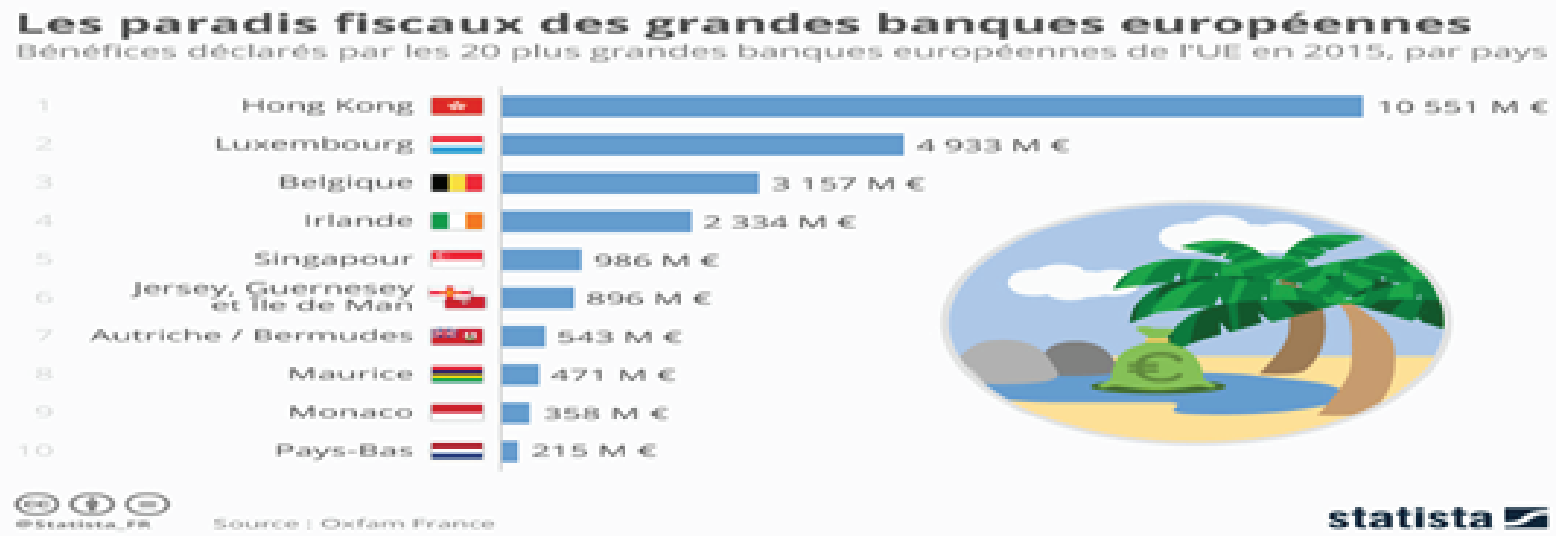

Not even China would be able to ignore a common position of USA and EU; so how is it possible to explain that, for example, British virgin islands are able to achieve the feat to survive against the willingness of G20' countries? Only one answer is there acceptable to understand this miracle: in spite of their official declarations, big states are less determined that they affirm, to wipe out tax heavens!

Worst, they seem to use them. Here, the purpose is not to speculate about doubtful operations initiate by states, but to question breaking tax heaven ban, are immune of any reproach...

In fact, beyond the low level of taxation, the greatest interest of tax haven is to create areas of shadow mainly thought two juridical mechanisms:

\section{JURIDICAL OPACITY}

Law usually wants the owner of things or rights to be identified for at least tree reasons: knowing who to tax; knowing who to sue, in case of problem (responsibility); and knowing who to protect in case of litigation

${ }^{20}$ Or International Business Corporations (IBC) 
about the rights at stakes. That is exactly what tax havens make impossible.Juridical opacity challenges those aims, mainly the fiscal one. By disconnecting ownership from the thing owned, it is a way to divert moral personality from its juridical nature (FOUMDJEM 2011). It is constitute by a set of rules imagined to separate the financial earnings from juridical risks. This aim may be reach by many ways and may be sophisticated. But commonly, it consists to create an intermediary moral personality, itselfcontrolled by a representative of the anonymous owners: shell companies ${ }^{20}$ (CUTUJAR et DIENER 1998);Anstalt(GLOS 1984) and trusts(BELLE-ANTOINE 2013).

Profit made are then (not)taxed locally at the name of the companies or their representatives and the real beneficiary of the sums stays in the shadows of the tax havens.

\section{BANK SECRECY LAWS}

As a principle, banking information's about their clients is not public ${ }^{21}$. Legitimate bank secrecy may be define as a duty, for people who are working in a bank, whatever their statute, to keep confidential,information's they know about their clients or about third parties $^{22}$. To infringe this duty may expose banker to professional, civil and criminal prosecutions. (LASSERRE CAPDEVILLE 2015)In fact, the problem occurs only when bank secrecy is diverted from it purpose of protecting bank customers to become a way of fraud or of committing crime; so mainly when opposed to tax or custom authorities in their legal missions.(NÉEL 2000) Even if the absence of requirement to provide annual account may preclude access to data required for an analyses of economic effects of a regime (OECD 1998, 18), bank secrecy is the angular stone of aggressive tax planning, tax optimizations and, of course, of all the grey economics. The efforts ofOECD tofightagainst seems to become effective: it is disappearing in many countries usually considered as tax havens likeSwiss \& Austria(OECD 2007) and we also see the first large scale international common investigation in march 2017. Nevertheless, bank secrecy stay a major point of qualification of tax haven that survives mainly because big states still tolerate it. Trough this first section, it is now clear that tax havens have generally been created by big state to serve their interests and that they survive mostly because of the lack of effective willingness of greats nations to eradicate tem. In a second step, it will be demonstrated that those same big states are no so virtuous that they use to say.

\section{"VIRTUOUS" STATES: THE FREEDOM TO BARGAIN FISCAL EQUITY}

Equity is a main concern in democracies (CAILLON, LASCOUMES, \& BARTHES, 2014). In particular, fiscal equity ${ }^{23}$ :"One of the most important attribute of any responsible tax system is equity. An effective tax system must not only be equitable, it must be perceived to be equitable."(SCOLARO 2006, 126) This particular link between "tax burden" and "contributive capacity" of taxpayer, whatever physical or moral persons, has beenstated for the first time in the "Déclaration des droits de l'Hommeet du citoyen" (1789, Art 13) and universalized in 1948, by the Universal Declaration of human rights ${ }^{24}$. Often granted by constitutions, this principle is fundamental in democracies 25 because it contributes to make society for two reasons(CAILLÉ 2010). First, it empowered the citizen as a member of a particular society ${ }^{26}$. Second, it is the base of the indispensible agreement to the taxation.

\footnotetext{
${ }^{21}$ Bank secrecy's principle is written in most of the world legislations.

${ }^{22}$ Legally, this duty is dual: a civil duty of « discretion » and a professional duty to keep the professional secrecy. Il est conseillé au professionnel de se « construire une demeure d'où rien ne transpire au dehors de ce qui se fait à l'intérieur » (Recommandation de Léon Battista Alberti citée par R. Farhat, Le secret bancaire : étude de droit comparé, LGDJ, 1980, p. 19.)

${ }^{23}$ (CLERC 2010) (DELALANDE 2001)

${ }^{24}$ See (R. MURPHY 2014)

${ }^{25}$ On the importance of fiscal equity for economy and society, see(ROUGÉ,2016) (REBELL 1998)

${ }^{26}$ Which is gradually disappearing in most of the states, mainly due to the lake of equity of most tax systems (BARILARI 2007) (BARILARI 2000) (CROUY-CHANEL 2014)
} 
So, the second stage of this analyze will aims to throw light onarrangements, "virtuous" states; use to practice against fiscal equity:Harmful tax competition, first. Then, the imaginations most of the states may deploy to blow finally up every notion of fiscal equity.

\section{THE HARMFUL TAX COMPETITION: AGOLDEN PATH OF THE LEGAL TAX OPTIMIZATION}

Tax optimization is often allowed, even favored by states laws. It create hence an incentive for other states to enter a tax competition to protect their fiscal income, and so on... (ROUGÉ \& CHOPOV, 2016) Harmful tax competition refers to tax practices which affects the location of financial or other service activities, burdens on tax authorities and taxpayers. Long time ago, OECD draw up the main techniques of harmful tax competition between states; nearly two decades later, the situation barely evolved...maybeis it worst today! Obviously, those techniques constitute archetypes. In practice, most states use a mix of them to create an optimal tax offer. In the worst cases, it is often combined with a strategic management of tax civil servants aiming at moving away the most qualified ones from the most sensitive briefs.As soon as 1998, OECD warned(also) against the fact that those practices "encourage corruption and discriminatory treatments, especially if not disclosed" "A specific example of this issue is where the tax authorities deliberately adopt a lax audit policy as an implicit incentive to taxpayers

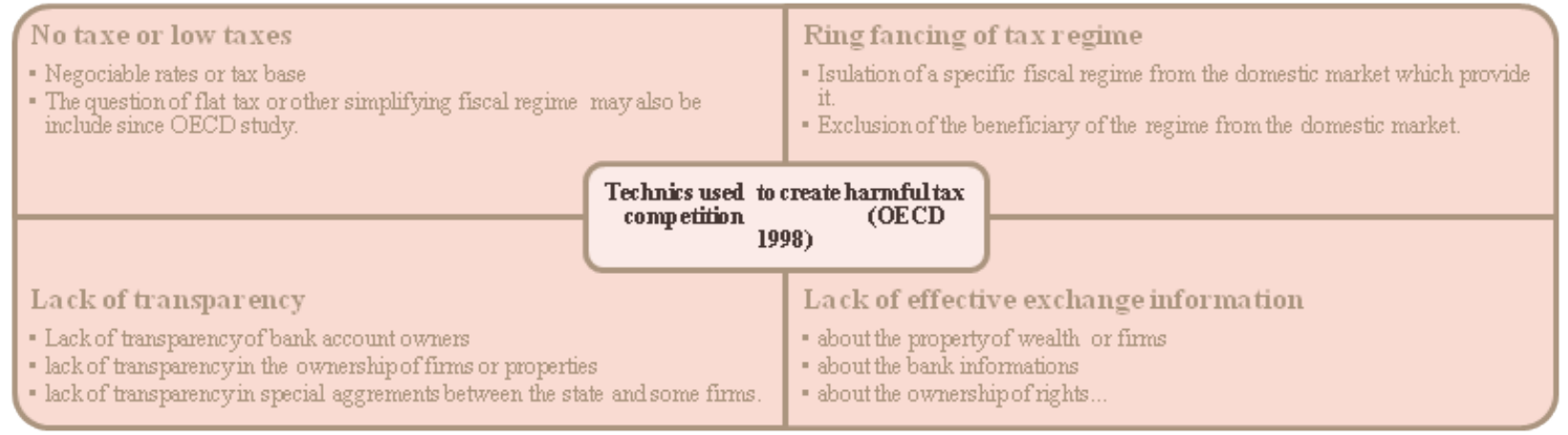

erodes the tax base of others countries, distort trade or investment patterns and undermines the fairness, neutrality and broad social acceptance of tax systems generally (OECD, 1998, p. 8) The damages of harmful tax practices are perfectly identified (OECD, 1998, p.16):distorting financial and, indirectly, real investment flows; undermining the integrity and fairness of tax structures;discouraging compliance by all taxpayers;re-shaping the desired level and mix of taxes and public spending;causing undesired shifts of part of the tax burden to less mobile tax bases, such as labour, property and consumption; andIncreasing the administrative costs and compliance not to comply with the tax laws. Such behavior may give these taxpayers a competitive advantage" (p.29) In practice, it is impossible and will not be interesting to draw an exhaustive list of the practices, we denounce $^{27}$. Let us concentrate on the most common and most important ones: In practice, it is impossible and will not be interesting to draw an exhaustive list of the practices, we denounce $^{27}$. Let us concentrate on the most common and most important ones: All those practices are perfectly known and documented for thirty years, firstly though OECD "special reports". But as efficient they may be, they are 


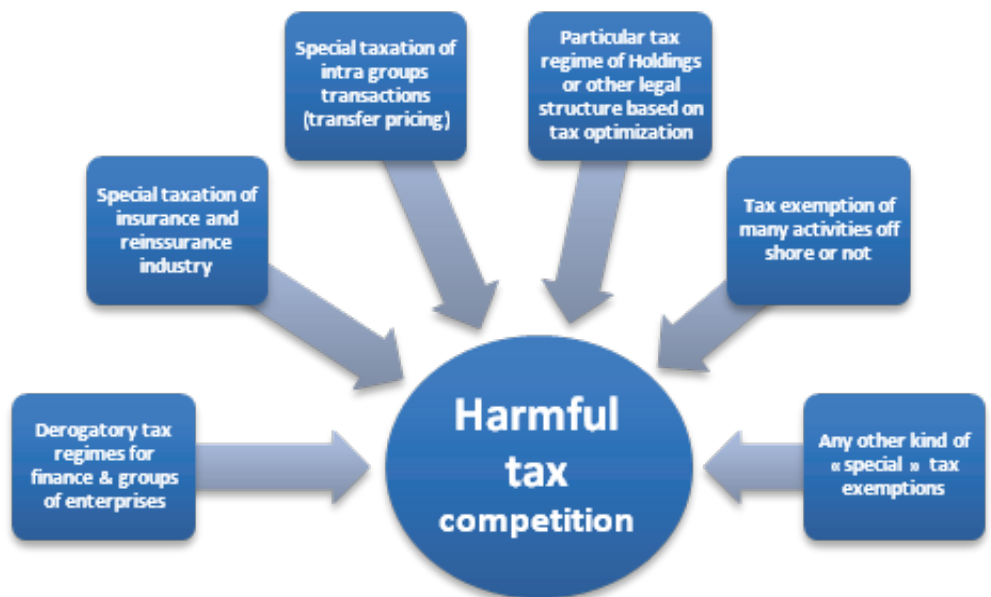

still not enough and it is possible to identify much perverse fiscal practices.

\section{THE IMAGINATION OF LAW TO OBLIT- ERATE FISCAL EQUITY}

A good tax system has to be fair and neutral. Fair, it has to share out the burden of public spending between all citizens; neutral it should not favor or put at unfair disadvantage any human activity. Fair and neutral, it purposes have to be financing fair and neutral spending(SIMONNOT 1998, 402). Despite its huge importance, cotemporary tax laws essentially ignore fiscal equity. The constitutional tax precept "to each one according to its contributive capacity" became, since a long time, "to each one according its power to obtain fiscal benefits". Hence, states compete with imagination to pervert their tax systems in order attract people ${ }^{28}$ or activities that politicians think to be good for the common good...or for themselves!(ROUGÉ et CHOPOV 2016)

Means to put at stake fiscal equity only limited by the imagination of civil servant that draw them $^{29}$, so it is impossible to be exhaustive. So, let us concentrate on particularly used techniques.

\section{THE NEGATIVE TAXATION}

Negative taxation occurs when states ortheir administrative sub-entities, give taxpayer money to sustain or attract economic activity. This simple fact hurts deeply fiscal neutrality and may be a source of corruption (DELSOL, 2014). Nevertheless, it may eventually be understand when done for social purpose. It is much more disputable when this money is given directly or not, to the benefit of "for profit" entities. Generally presented asefficient tools of economic policy, to shape investment, preserve or increase employment, stimulate demand or offer, OECD reports the harmful consequences of the main type of negative taxations: the subsidies and the corporate tax incentive.

SUBSIDIES are current payments by the general government or European Union institutions to resident producers that are not required to be reimbursed ${ }^{30}$. According to the definition given by Eurostat ${ }^{31}$, the overriding goal is to influence levels of production or prices, or to compensate producers for production costs. A first problem with subsidies is that it is in contradiction with the core philosophy of the neo-liberal paradigm that most governments of big nations follow. A second one, much more critical, is pointed out by M. AKASAKA, OECD deputy secretary general: « Subsidies often introduce economic, environmental and social distortions with unintended consequences. They are expensive for governments and

\footnotetext{
${ }^{28}$ For example, Portugal just decided an exoneration of taxes on revenues for 10 years for everyone who comes to live in the country.(DUMONT 2017). Italia is changing its tax system for the same reasons in march 2017. England of the brexit and USA under the new presidency are taking the same way. ${ }^{29}$ For example tax concessions, soft loans, or even equity participation.

${ }^{30}$ Nature of subventions (ROUGÉ et CHOPOV, 2016) Sometimes, subsidies are granted through an administratively fixed price of supplying (for example « le tarifbonifie » of eolitic electricity (DELSOL 2014)) or an adminitrativelly fixed price of sale (Medicines in France)

${ }^{31} \mathrm{http}: / /$ ec.europa.eu/eurostat/statistics-explained/index.php/Glossary:Subsidies
} 
may not achieve their objectives while also inducing harmful environmental and social outcomes"(...) « Government support for certain sectors and economic activities are pervasive in OECDcountries and among the most powerful public policy instruments now in use. "(OECD 2007, 7). One may not be clearer! Subsidization of (industrial) activities distorts the allocation of scarce resources, is a burden on government finance and generates friction in international trade $(\mathrm{OECD}, \mathrm{FORD}$ et SUYKER 1990). Despite those decisive critics, subsidies are largely used around the world,worst; they seem to increase, as showed by the map below ${ }^{32}$ : though fiscal exonerations or reductions. As seen below, they may have a huge impact on economic decision and may constitute a massive distortion of competition's fairness. Even thought, those states' actions may be less detrimental of fiscal fairness than the "laisser faire" in bookkeeping regulation.

\section{THE BOOKKEEPINGREGULATION}

Rigor of bookkeeping is essential to preserve fiscal equity; but many loopholes characterize unfortunately accounting regulations and accounting rigor is far from being enforced

\section{Subsidies and other transfers (current LCU)}

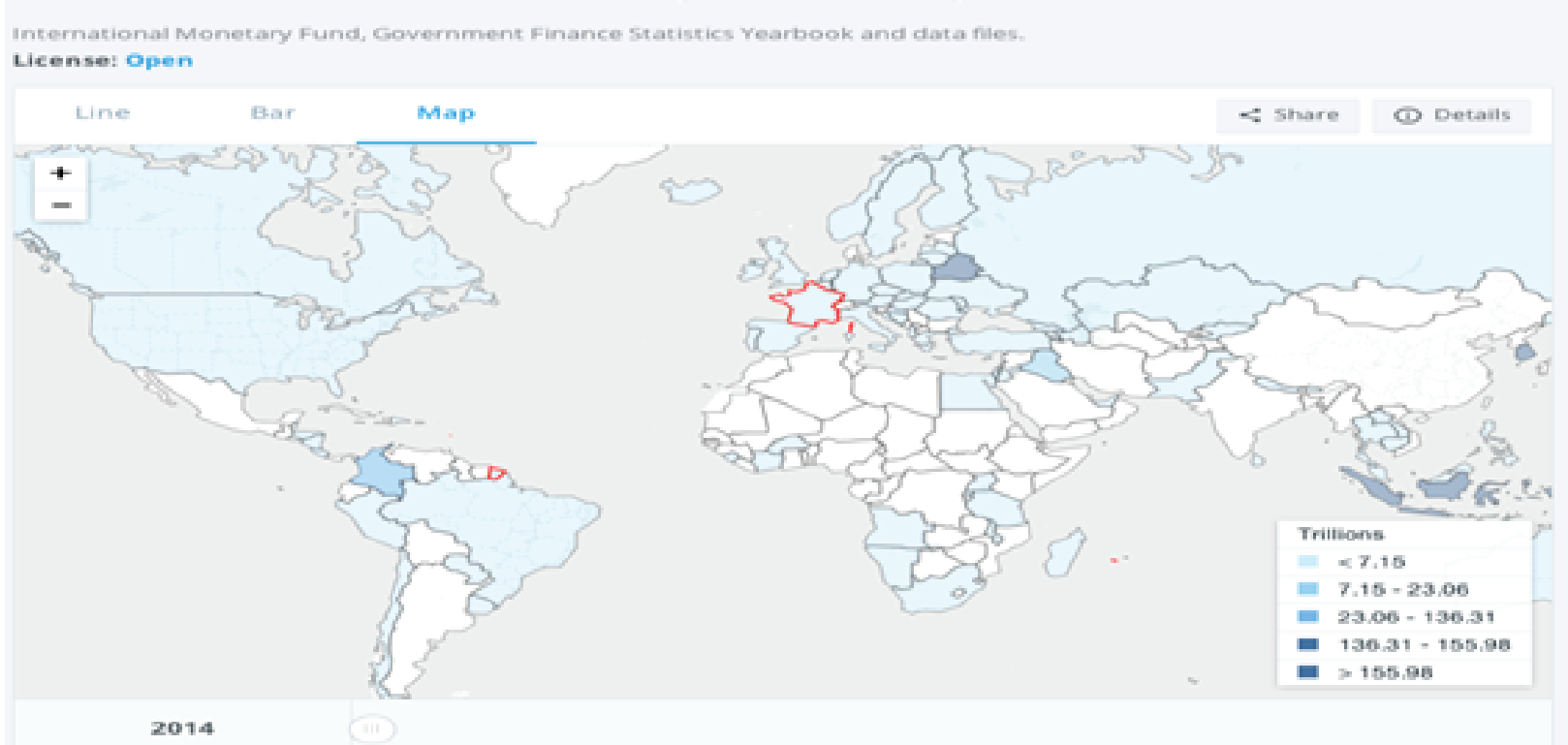

Overview per country

country

1980 (thousand)

France

7.759 .654 .98

2014 (thousand)

$566,481,000,00$

And according to their huge negative side effect, it may be proposed that the reason to use subsidies is to fight the global tax war $^{33}$.

CORPORATE TAX INCENTIVE sare also denounced by OECD, mainly those related to FDI (OECD, 2001). Contrary to the subsidies, incentives generally not paid directly, but by law. (J. STIGLITZ 2003)(J. STIGLITZ 2003). Hence, bookkeeping regulation is the heart of tax optimization.There is generally no need to fraud, but to master accountingtoescapetaxes. And when mastering technic is not enough, then imagination take the power to save still more taxes.

\footnotetext{
${ }^{32} \mathrm{http}$ //data.worldbank.org/indicator/GC.XPN.TRFT.CN?end=2014\&locations=FR\&start=2014\&view=map

${ }^{33}$ Even if it is a main concern for this topic, we deliberately exclude the link between subsidies and corruption. For an exemple « Le Service central de prévention de la corruption souligne dans son rapport d'activité 2013 que «Le développement de l'activité éolienne semble s'accompagner de nombreux cas de prise illégale d'intérêts impliquant des élus locaux ». Ceux-ci définissent les zones de développement éolien ou autorisent les permis de construire de telle façon qu'ils puissent valoriser leurs propres terrains, avec des profits substantiels à la clé. Le rapport du SCPC alertes sur les risques d'" atteintes à la probité beaucoup plus graves comme celui de la corruption ». http://fr.irefeurope.org/Le-vent-des-subventions-et-de-la-corruption, a3129
} 


\section{MASTERING OF THE TECHNIC.}

Accounting technics are a fabulous way to minimize tax legally (and more or less fairly). It is impossible here to describe all the way open by law. The most famous are probably:

\section{The Deductibility of interest payments. Debt} is a normal way of financing firms. Then, it seems perfectly normal that interests paid on the debt need to conduct activity (which will generate profits, then taxes) may be considered as an accounting charge and so be deductible. The problem emerge when global firms, despite a huge amount of casch reserves, significantly increase their debt level, at home in order to mitigate their corporate tax via deducting interest payments when, at the same time, profit are registred in tax haven subsidiaries ${ }^{34}$ " therefore enhancing the value of the firm and potentially creating a temporary boost in share price and creating a lucrative impact on employee stock options. »(JONES et TEMOURI 2016, 241)

The evaluation of the assets is also a main question of a fair accounting. It is in fact very difficult to determine the actual value of an asset, or even of a debt. Traditionally, in Europe, it was based on the principle of prudance. But, with the adoption of IFRS, Europe joint the anglosaxon way to estimate the vaalue of things by "the market". A main caracteristic of this kind of valuation is its volatility and its subjectivity when there is no market of reference; which is often tha situation. So, it is quite simple to fix subjective depreciations or appreciations of asssets to reach fiscal targets (FREEDMAN 2008)
The provisions in general thoseof bad debts, in particular, are at least a very common way to adjust the financial result of corporations to tailor taxes...

This list is far from being exhaustive. The point here is to insist on the fact that all those technics are economically legitimate but that they are also commonly used to minimize taxation in an unfair way. Of course, that is much less reprehensible that creative accounting.

CREATIVE ACCOUNTING. Identified in 1986 by GRIFFITHS, creative accounting is since very common ${ }^{35}$. It consists in using the flexibility within accounting to manage the measurement and presentation of the accounts so that they serve the interests of preparers(M. JONES 2010) It is within the limits of law,it follows accounting standards, and thus it obeys the law butnot its essence.(JAMESON 1988).For example a firm may use Tax shelters ${ }^{36}$; Emission of tax exempt bonds ${ }^{37}$ : or the buyback of its own share ${ }^{38} \ldots$

To manipulate accounting figures, accounting professionals, use many technics, which aims to create a misinterpretation of financial information for stakeholders. Accounting scandals spreading all over the globe, are there to prove that accounting numbers may be easily manipulated so as to deceive and defraud(M. JONES 2010)In the figure below(DUR-e-SHAWAR et QAISAR $2015,149)$ draw up the divers ways creative accounting may be used to escape taxes. ${ }^{39}$

Clearly, fiscal equity is at stake despite the core principle of accounting. So is it with some fashionable tax systems.

\footnotetext{
${ }^{34}$ Even if the profits accumulated in tax havens subsidiaries may later be used as a strategic weapon, in order to be able to shift capital rapidly across the other subsidiaries.(ALTSHULER et GRUBERT 2003) (HINES et HUBBARD 1990)

${ }^{35}$ Since, many technics complete the palette (JONES 2010):

Aggressive accounting: «It is the use of accounting rules and regulations to deliver a particular set of financial results. It involves a deliberate choice of accounting figures, which will have more to do whit achieving a specific managerial objective, rather than representing a true and fair view. Earning management academic term for aggressive accounting

Impression management is not fraudulent. It is normally more associated with the presentational aspects of reporting (accounting narratives, graphs \& photographs) to influence financial reports in favor of management.

Profit smoothing: as stock market rewards companies that produce steady profits and penalize those with erratic profits, profit smoothing is the use of various technics to smooth profits.

${ }^{36}$ US General Accounting Office defines abusive shelters to be « very complicated transactions promoted by corporations and wealthy individuals to exploit tax loopholes and provide large, unintended benefits » $(2003,1)$ Those shelters are a huge source of tax looses. Studies documented a growing gap between the book income reported on public corporations 'financial statements and the tax income of corporations after tax retreatment. (DESAI 2003) (MANZON et PLESKO 2001) (BANKMAN 2004)

${ }^{37}$ States and local governments use to finance their needs of money byissuing bonds. Sometimes the interests on those bonds are tax exempted to attract investors or special categories of investors. Tax-exempt bonds are an opportunity to shelter income to taxation. Because the bonds are most valuable to taxpayers with high marginal tax rate, they offend the equity of taxation by reducing the progressivity of the tax' burden by income class. ${ }^{38}$ When a firm buybacks its own shares, the tax on value added realized by shareholders is generally much less that the taxes they will pay on dividends (PIKETTY 2013, 280)

${ }^{39}$ Definitions from: http://www.investopedia.com/terms

Earnings management is the use of accounting techniques to produce financial reports that present an overly positive view of a company's busines activities and financial position. Many accounting rules and principles require company management to make judgments. Earnings management
} 


\section{FROM THE FLAT TAX SYSTEMS TO THE UNIQUE TAX SYSTEM}

The impact of flat tax systems on fiscal equity has already been demonstrated, previously (ROUGÉ et CHOPOV 2016). A new version, even more inequitable has just been created, in March 2017, by Italy, which just invent the inclusive tax system for wealthiest. Progressivity of taxes has been erase for the profit of a unique amount of taxes, whatever the amount of income or wealth, of 100000 euros.

\section{* \\ $* *$}

The panorama captured by this section is not equivoque: states are fighting a selfish and pitiless war between themselves to attract wealth; whatever the pettiness and consequences for public good. Even the border between "renegade" and "virtuous" states fades in from of the manipulations of their tax law usually practiced by the last one. The abdication of great states finds no excuses, but may partially be explained by the cynical game some global enterprises play.

\section{THE CYNICALGAME OF MANYGLOBAL ENTERPRISES}

\section{"L'économie est au service du bien commun; elle a pour objet de rendre le monde} meilleur"40 (TIROLE 2016)

This precept seems totally away from many global firms which purpose seems only to make money for money; today and whatever the price. Concerning fiscal topics, even if he is violently criticized ${ }^{41}$, PIKETTY $(2013,800)$ speaks of "fiscal secession of the wealthiest"; on this point, he seems not to abuse. The situation seems obvious: "Big technological

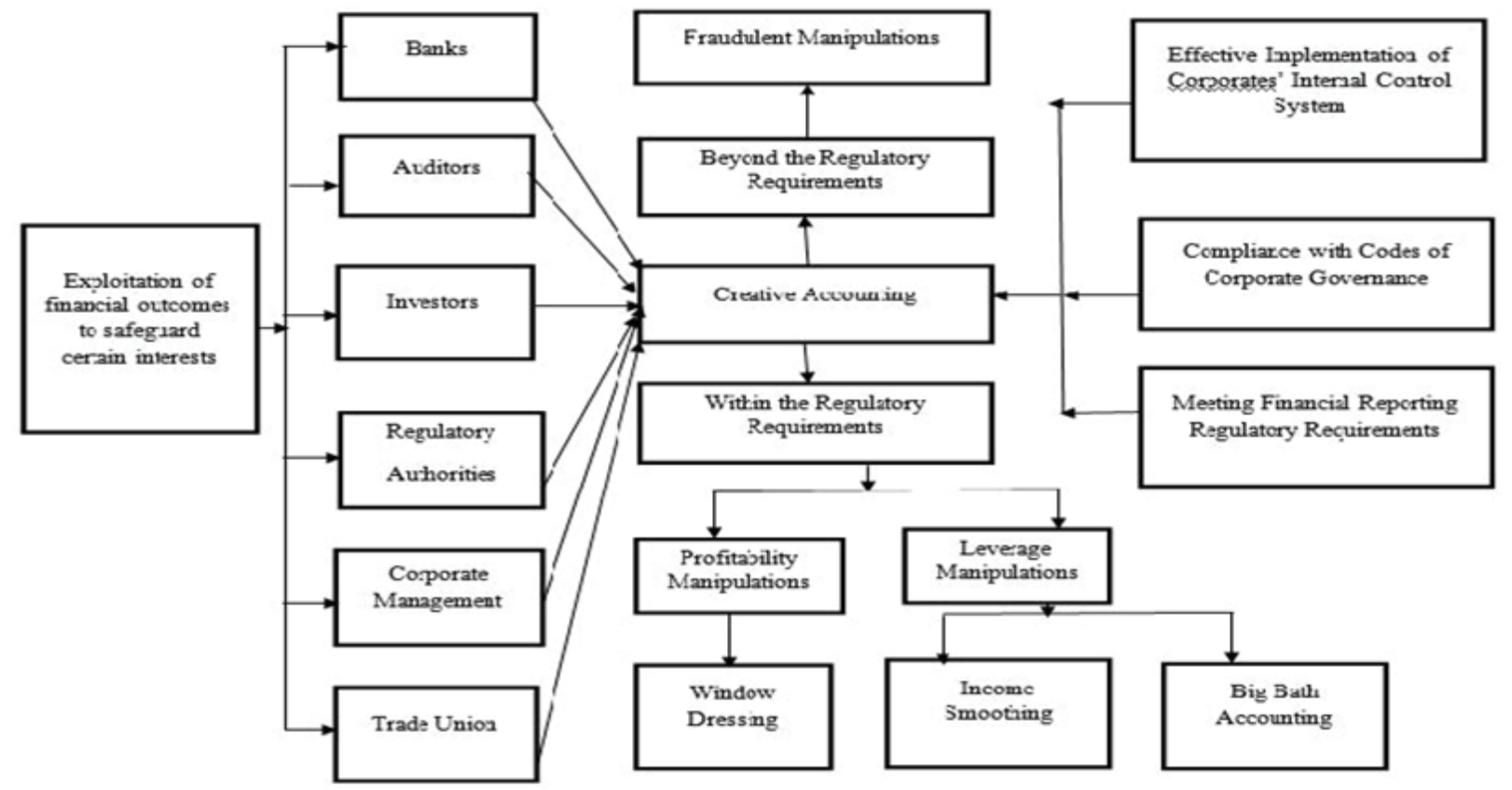

takes advantage of how accounting rules are applied and creates financial statements that inflate earnings, revenue or total assets. »

Window dressing(« Window dressing is a strategy used by mutual fund and other portfolio managers near the year or quarter end to improve the appearance of a fund's performance before presenting it to clients or shareholders. To window dress, the fund manager sells stocks with large losses and purchases high-flying stocks near the end of the quarter. These securities are then reported as part of the fund's holdings. "

window dress, the fund manager sells stocks with large losses and purchases high-flying stocks near the end of the quarter. These securities are then reported as part of the fund's holdings. »

Income smoothing ( $«$ The use of accounting techniques to level out net income fluctuations from one period to the next. Companies indulge in this practice because investors are generally willing to pay a premium for stocks with steady and predictable earnings streams, compared with stocks whose earnings are subject to wild fluctuations.

A big bath is an accounting term defined by a management team's strategy of manipulating a company's income statement to make poor results look even worse to make future results better. It is often implemented in a bad year for a company to enhance the next year's earnings in an artificial manner. »)

${ }^{40}$ Free translations: Economy aims at the common good; its object is to construct a better world.

${ }^{41}$ Capital in the XXI ${ }^{\circ}$ century is qualified of "intellectual fraud" by many researchers in economics and management. (LECAUSIN, DELSOL et MARTIN 2015)

${ }^{42}$ In 2012, President OBAMA, in his « President's Framework for Business Tax Reform », pointed out that « empirical evidence suggested that the income shifting behavior by multinational corporations is a significant concern that should be addressed through tax reform »

${ }^{43}$ Some economists nevertheless consider that taxing corporations is not only a bad thing, but also unfair(MARTIN 2016): Firms earning bear a double taxation (profits of the firm and incomes of shareholders); tax are also bad for employment and workers and for economic growth...

${ }^{44}$ In the competition between "civil law » and « common law », the procedural nature of the common law makes the compliance to the strict letter of the law, the norm when civil law may also more easily use the spirit of the law, to enforce principles. (J. ROUGÉ 2013) 
firms are, as a principle, opposed to taxes, what is provoking the ruin of States" 42 (B. MURPHY 2012) (3) $^{43}$.Their lawyers and accountant have developed a true art, of escaping taxes, without breaking openly the law(MALGORE 2016) ${ }^{44}$ ! When auditioned by senatorial or representative commissions for their aggressive tax practices, their CEO used to be "very surprised to be treated as accused of some crime". They generally conclude their audition telling something like: we always follow the law; if you disagree with our practices: change the law. The cynicism is at its peak!

No, in fact not. Cynicism may be still higher. Because if there is few doubts that, in the light of the public live, global firms use to follow the law, or even seem to be socially responsible(DAVIS, et al. 2016), in the shadow of the business, they use to circumvent it.First, they routinelymultiply artificial streams of goods or money without any economic justification, but to escape taxes (PIKETTY 2013, 307); it is one of the main reasons why $60 \%$ of all international trade never sees the market ${ }^{45}$ to take place in internal firm transaction. And curiously, transfer pricing has become one of the most problematic topic of international tax law and particularly in tax evasion $\operatorname{law}^{46} \ldots$ But it will not be the subject here ${ }^{47}$. Even more; global firm are keen to manipulate states, or international organization, like European Union, to obtain what they want. Hence, after creating it, theyturn out to be expert in the art of stimulating Hypercompetition between national tax systems(ROUGÉ et CHOPOV 2016).

To understand those hidden practices, the present section will first, insist on the ways global firms put national tax systems in competition(ROUGÉ et CHOPOV 2016). Then,it will demonstrate, how they fight to shape lawsthey eventually tailored.

\section{THE VIRTUOSITYIN ESCALATING HARMFUL TAX COMPETITION}

Harmful tax competition has been analyzed in the previous chapter, but it is interesting to insist here on the technics used by global firms to keep pressure on tax systems to create Hypercompetition between them. Two of them are particularly used: first, global firms like to choose their law; then they generally discus the effective application of those laws directly with tax authorities.

\section{A SKILL TO ABUSE TREATIES NETWORKS}

The world, and particularly the world of international business, is supposed to live in an environment of freedom. That's a wonderful thing for which we have to care about. But freedom has a particularly fundamental corollary: responsibility. When this last one disappears freedom may easily become chaos where only the law of the stronger is the one enforced.To smooth that fierce law, treaties are the way states use to limit their own power to facilitate exchanges with other nations. But, far from favoring this way to live together, "Countries that have introduced regimes constituting harmful tax competition often view the development of their network of tax conventions as an asset that facilitates and encourages the use of these regimes by residents of third countries."(OECD 1998, 47) Abusing of their freedom, global firm hence use to put states laws in competition, to abolish as many (fiscal) constraints as possible. As point out by OECD, “an extensive treaty network may open up the benefits of harmful preferential tax regimes offered by the treaty country to a broader array of countries than would otherwise be the case. One of the motivations for extending the treaty network in some countries may be to enhance the benefits of harmful preferential tax regimes." (OECD 1998, 33)

\footnotetext{
${ }^{45}$ Neoclassical theory of the market may be criticized but the market has also virtues: as a meeting point for an offer and a demand it puts in light many useful information essential for tax purpose: prices and quantities... Without market the shadows of the internal transactions was certainly a progress when the firm was integrated (and small enough) (COASE 1997); it is a danger with global network firms.

${ }_{46 "}$ Transfer pricing allows an MNE to minimise its corporate tax liability by setting appropriate prices for intrafirm trade and offers the ability to defer taxation into the future." (JONES et TEMOURI 2016, 238) (SIKKA et WILLMOT, The dark side of transfer pricing, 2010)

${ }^{47}$ See (ROUGÉ et CHOPOV, 2016)(ARMSTRONG 1998)(BOYRIE, PARK and ZDANOWICZ 2005) (OECD, 2001)(OECD, 1979)(RUGMAN 1985)
} 
OECD identifies "treaty abuse, and in particular treaty shopping, as one of the most important source of Base Erosion and Profit Shifting concern" (OECD 2015)Hence, for nearly forty years now ${ }^{48}$, one of the most efficient ways to optimize its taxation is the allowance, given to taxpayers by states to choose their law. "Taxpayers engaged in treaty shopping and other treaty abuse strategies undermine tax sovereignty by claiming treaty benefits in situations where these benefits were not intended to be granted, thereby depriving countries of tax revenues" (OECD 2015)Still more disturbing is the fact that, in the absence of reciprocity and procedural fairness the fact by a country not to collaborate with other in such e matter is a very important aspect for encouraging tax evasion.(OECD 1998, 51)

Of course, since it has been identified like a source of unfair practices, more and more internal laws and treaties include anti-abuse provisions, including a minimum standard to counter treaty shopping. The remaining question is: why is treaty shopping still in common use? One answer may be that many states, despite their international engagement to do it, do not really look for enforcing their own law, due to the pressure they suffer to become fiscally attractive. This phenomenon is reinforced by the global corporations habit to negotiate their tax burden with public authorities before engaging in FDI.

\section{ATALENT TO NEGOTIATE THE APPLICATION OF THE CHOSEN LAW}

Politicians and tax practitioners often claim that tax uncertainty, justify the possibility forfirms to request fee-based advance tax rulings (ATRs) to mitigate $\mathrm{it}^{49}$.(DILLER, et al. 2016)(ALARIE, et al. 2014).
The more tax systems are complex, the more tax rulings may be "vital"(SCOLARO 2006, 130). Hence, OECD's work demonstrates that "there has been a trend from 1990 to 2013 among OECD countries to adopt advanced tax rulings regimes (...) in practice, 34 member countries have adopted tax rulings ${ }^{50}$ "(ALARIE, et al. 2014) that seemto be considered as "best practices" to follow and encourage tax administrations to adopt biding rulings regimes.There are commonly two sorts of tax rulings ${ }^{51}$ :

- « Public ruling » or « revenue ruling » is issued by the legitimate tax authority, at its own discretion to provide the public with its opinion on the way in which tax law applies to a person or a class of persons, in relation to an arrangement or class of arrangements. Public rulings are generally published.

- " Private ruling »: are issued by the legitimate tax authority only upon the application by a taxpayer. The authority is generally obliged to issue private ruling upon request and these rulings apply inly to the applicant taxpayer. It provides him the authority's opinion on the application of taxlaw to a specific arrangement that tax payer has entered into or proposes to enter into.(SCOLARO 2006)

Tax rulings have been created with two purposes(JAMES et WALLSCHUTZKY 1995):

- To promote certainty ${ }^{52}$ for taxpayer and thereby reduce their risks and opportunity costs ${ }^{53}$.

- $\quad$ To make the tax systems "fairer because taxpayer will be able to object private rulings and have the matter reviewed by an independent tribunal or court." (SCOLARO 2006, 113) Fostering uncertainty on the part of taxpayer may increase their level of compliance and then be advantageous for the revenue authorities ${ }^{54}$. A third advantage supposed of rulings is that

\footnotetext{
${ }^{48}$ This concern is not new. At the end of the 1980', treaty shopping was already an up to date question.

${ }^{49}$ The factors to consider before to apply for tax rulings are:the possibility of an unfavorable ruling:the length if time needed to obtain the rulings: the risk of revenue querying issues not anticipated by the taxpayer and unconnected to the transaction for which a ruling was sought.Source :(BELZ 1967-68)

${ }^{50} \mathrm{UK}$ has no formal system of advance rulings but Her Majesty Revenue \& Custom provides an extensive clearance service for business taxpayers. ${ }^{51}$ In France tax ruling is named « rescrit fiscal » by the law of July 8, 1987, which created it. (COIN, DURAND et LIEB 2010)

${ }^{52}$ The authors precise that this reflects the basic tenet of Adam SMITH's principle of Certainty in " An inquiry into the nature and causes of the wealth of nations »

${ }^{53}$ Tax authorities are bound by a ruling unless the facts were incorrectly described. "The basic concept underlying tax rulings systems is that taxpayers are entitled to know how to calculate their liability for tax before or at the time of entering into a transaction rather than learning the tax outcome only after the transaction is completed." (ALARIE, et al. 2014, 366-367)

${ }^{54}$ (LOGUE 2007) (SCOTCHMER et SLEMROD 1989)According to (ALARIE, et al. 2014, 367), « The economic intuition behind these arguments is that risk adverse taxpayers will err in the side of caution and perhaps over-comply with strategically uncertain tax law. »
} 
they are an important source of information for governments.(ALARIE, et al. 2014, 368)

Despite those legitimate arguments, rulings are under cautions du to the abuses revealed among others by the case EU vs APPLE in fall 2016. For example, when a global firm approach simultaneously several governments to consider a foreign direct investment, ruling may be use to negotiate an abusively low, predetermined level of taxation in order to attract the future activities. By allowing specially negotiated privileges to very powerful clever corporations, some states pervert a system that otherwise may be benefic: "Our results also hold when the tax authority maximizes social wealth instead of its revenues. Regulatory changes in ATR requirements might serve as a natural quasiexperiment for an empirical study of our predictions regarding investment decisions" (DILLER, et al. 2016). The problem then become one of unfairness of the fiscal treatment due to your capacity of negotiating; many recent scandals tend to show that it is a huge one. But such a bargaining skill is not the only way to tailor fiscal regulation.

\section{THE HIDDEN TALENT OF TAILORING THE LAW}

In this section, the question that will be treated is "how to be sure to get the best law to sue its own interests?" The answers proposed by global firm are both simple and very efficient: make them ourselves!

Chocking? Maybe, but to legal ways have been developed to bypass the obstacle of the democratic rule that wants the law to be decided by the representative of people for the common good. The first one is to convince the legislator that he is not really concerned by the matter: the self-regulation will be more efficient. The second, when this first way is close is to prepare the law, to let to the legislator the "freedom" to approve it.

\section{THE ART OF DEVELOPING SOFT LAW}

On of the greatest virtuosity of global firm is to be able to convince regulators, sometimes even the entire society, that they are the only one to understand their business enough, to regulate it. Hence, auto regulation should be the rule; the law; the exception. In a perfect world, it could be right. In the world of greediness of global firms it is a plain nonsense commonly accepted.

"The generic term soft law covers a wide range of instruments of different nature and functions that make it very difficult to contain it within a single formula. Its only common feature is that it is in written form, but the other characteristics are variable and negotiable and they constitute an "infinite variety." So the term encompasses soft rules that are included in treaties, nonbinding or voluntary resolutions, recommendations, codes of conduct, and standards."(FAJARDO 2014).

Two technics are usually used to accomplish this exploit. As long as it is possible, firms promote auto regulation, excluding states from process but to enforce its results. The masterpiece of this art is the accounting regulations. And when, due to the abuses of freedom, the masquerade is over, the genius is to convince regulator to endorse only "not binding" regulations.

\section{THE ABUSES OF SELF-REGULATIONS}

"Rules" may legally be set down precisely, by the one who have to follow them: "standards", "codes of conduct" "voluntary resolution"; or even more evasive: "nonbinding resolutions" or "recommendations".(RADELLI 2003),

The argument in favor of auto regulation is right: the more a matter is technical and evolving, the less law is the adapted tool to regulate it. The time of the law is obviously not the time of business; even less the one of finance(OST 1999)Problems begin when, in our society most of the global business is complex, volatile and international. It 
questions about the relevance of states lawsas a tool of regulation. Further, it question about the place of any democratic tool to regulate economics... but that is a larger question.

Here, we just want to insist about the dangers of self regulation and particularly, as long as taxes are concerned, of the brightest one: accounting. The place is missing to here, so the reader will be invited to reread "the roaring nineties" and especially the chapters four and five(J. STIGLITZ 2003) But, soft law is not only self-regulation, it is also non binding public regulation.

\section{THE LIMITS OF NON BINDING PUBLIC REGULATIONS}

Except concerning the United States of America, which has the power to enforce universally their domestic law, it is important to remind here that law is territorial and global firms are a-territorial. No international institution but the Word Trade Organization dared to use its influence (power?) to fix internationally biding norms.

Regarding fiscal concerns, OECD then used for decades to fight fiscal abuses with incentive weapons: "guidelines" or "recommendation" or "codes of conducts". One can think that things are changing with the "Base Erosion Profit Shifting" (BEPS), at least conceived to be aenforceable tool of action(OECD 2015).

Future will tell us the effectiveness of this new international regulation ${ }^{55}$. But to secure their tax immunity, global firms are also master in the art of draining the fiscal burden out of their horizon.

\section{THE ART OF DRAINING ANY RESIDUAL CONSTRAINT FROM THE LAW}

In this section, the cynicism wills rich its apogee. Through a tree steps demonstration, it will be enlighten how global firm manipulate states fiscal laws to neutralize them to the maximum.

In fact, the method is quite simple. First, global firms use to finance politicians runs what is far from being neutral on the their level $\mathrm{f}$ taxation. Second, they use to propose their laws to politicians who often vote them without great resistance; it is usually called lobbying. At least, global firms comply at minimum to the law, they shaped.

\section{THE IMPACT OF FINANCIAL SUPPORT TO POLITICAL CAMPAIGNS}

If anybody wondered why big and global firms use to finance politicians of diverse wings during their run to the power, the answer is simple: it worth the spending! Very few academic literature document this point, fortunately recently, CHIRINKO \& WILSON (2010), have made a very interesting study on the impact of allowing American firms to subsidies political campaign.

The authors linked business campaign contribution to tax rate: " business campaign contributions may directly influence business tax rates, as well as indirectly shape tax competition, and enhance or retard the mobility of capital across jurisdictions. » (P. 968)Let us examine the conclusions of this paper:"Based on a panel of U.S. states and unique data on business campaign contributions, our empirical work uncovers four key results.

- $\quad$ First, we document a significant direct effect of business contributions on tax policy.

- $\quad$ Second, these estimates imply that the economic value of a $\$ 1$ business campaign contribution in terms of lower state corporate taxes is approximately $\$ 6.65$.

Third, the slope of the reaction function between tax policy in a given state and the tax policies of its competitive states is negative, and this slope is robust to including business campaign contributions in the econometric equation $^{56}$.

Fourth, we highlight the sensitivity of

\footnotetext{
${ }^{55}$ The first successes of this new regulation have to be notice: global firm have to report benefits country by country for the first time in 2016 . But it is possible to worry about the future of BEPS, when we look at the tax reforms in achievement in the USA of President TRUMP and in the England of Brexit..

${ }^{56}$ This negative slope reflects a reaction to an inflow of capital (due to an increase in capital taxes in neighboring jurisdictions) that creates an increase in capital taxes in neighboring jurisdictions) that creates an opportunity for residents to maintain the current level of public services at a lower tax rate; negative income elasticity for public goods compels residents to act on this opportunity.
} 
the empirical results to state effects ${ }^{57}$."

Impressive: as the title of the paper induce, it seems to be possible to buy its level of taxation: That even in a low corrupted country, and even in the absence of close collusion between economic and political power. Let us imagine what may really be when elected people are big business owners or chiefs of mafias... But it is still not enough! To be absolutely confident to minimize taxation, the best way for global firms is to tailor the fiscal law to their aims: and it works perfectly well.

\section{THE HABIT TO TAILOR THE LAW TO THEIR NEEDS}

The proverb tells, "to be sure that things are done properly, do it yourself". And that is just what global firms use to do. They pay their specialists to write the law that serve their interests, and propose the text to authorities. That is called lobbying, and it is perfectly legal, even recommended, like in the statutes of European community. Lawmaker use to count on lobbyists to prepare technical law:"A political climate that encourages tax lobbying is one where policymakers are willing to forgo revenue by expanding the set of tax preferences. A climate that necessitates tax lobbying is one where policymakers seek to increase revenue by curtailing the set of tax preferences. These climates, which often co-exist, create opportunities for strategic tax lobbying by firms seeking new tax benefits, or compel firms to engage in defensive tax lobbying to preserve existing tax benefits." (MEADE JA 2015)

Lobbying may be described as"a negotiation among several interestedparties rather than an exchange of dollars for specificlegislation" (RICHTER, SAMPHANTHARAK and TIMMONS 2009). It is so kind to those authors to sterilize the phenomenon through this "politically correct" definition. No, lobbying is not corruption ${ }^{58}$, but a power relationship between a firm or a group who knows exactly what are their selfish interests, and civil servants who have to define a "common interest" of the populations they serve (which is quite impossible) with less and less means of action and of independent sources of information, due to the politics of budget restrictions everywhere around the globe. If "the literaturedoes not provide very consistent answers aboutwhy some organizations lobby and others do not" (BRASHER and LOWERY 2006), the gain of lobbying is nevertheless perfectly documented: Tax benefits may take the form of direct tax savings from exclusions, deductions and credits, or indirect tax savings from strategies that exploit loopholes in the tax law. (MEADE JA 2015, 28). In practice, research and development intensity, return on assets, capital intensity and tax depreciation schedules tailored to specific types of capital equipment serve as potential channels through which politicians could manipulate the tax code to favor firms that lobby. "We expect the tax treatment of firms that lobby to be more responsive towards accruing benefits along these channels than firms that do not lobby". (RICHTER, SAMPHANTHARAK and TIMMONS 2009)

However, whatever the technical means used, and even if the battle for political influence does not distort the tax structure, what is doubtful, lobbying is cause of inefficiencies (BRUSCO S 2014). But the global firms' efforts to escape marginal taxes do not stop there.

\section{THE MINIMAL COMPLIANCE TO THE LAW THEY SHAPED}

Even with tax law tailored, and its application negotiated with tax authorities or directly with governments, the last weapon used by global firm to minimize effective tax burden paid is compliance. ROUGÉ \&CHOPOV (2016) largely discussed that

\footnotetext{
${ }^{57}$ In fact, the frontier between lobbying and corruption is perfectly defined even if hazy. As the example of M. BARROSO, in 2016, shows, the problem is much more one of conflict of interest. See also (ALET 2017)

${ }^{58}$ In fact, the frontier between lobbying and corruption is perfectly defined even if hazy. As the example of M. BARROSO, in 2016, shows, the problem is much more one of conflict of interest. See also (ALET 2017)
} 
question and it is enough to remind here that applied at minimum, on the sole basis of the letter of the fiscal text, the level of compliance is often everything but fair.

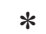

The aim of this section was to confront the affirmations of many global companies' CEO, according to which, they always follow the law; even if defendable this affirmation has to be nuanced... At least many of them do not follow the essence, the spirit of tax law. 


\section{CONCLUSION}

At the end of this study, it may be quite easy to conclude on a pessimistic note. If, according to $\operatorname{OECD}(1998,20)$, "globalization has had a positive effect on the development of tax systems, being, for instance, the driving force behind tax reforms, which have focused on base broadening, and rate reductions, thereby minimizing tax induced distortions". It also awaked many extremely powerful demons met during this work.Facing some very organized, clever and sometimes manipulative firms, mastering in the art of preserving their interests, states seem to be at least schizophrenic.

Nevertheless, the worst is never written. The situation progresses in from of our eyes, which make its evolution hard to

OECD, through its brand new BEPS's, anticipate but let place to optimism.Firstly, may finally have an effective tool to fight aggressive tax planning. This framework include more than 100 country, which is exceptional and seems, for once, to show the strength of states' willingness, despite the practices described above. Secondly, the civil society, tanks to the Internet and the TIC, and notably through the combats of Transparency International and Oxfam, is no more silent. Putting in light more and more abuses and non-ethic comportments, it action may hugely change usual practices, making them unbearable.

A quick way to make things easier may be to include international tax law in the competencies of the World Trade Organization. The reasons are obvious: Taxes, commerce and finance are inexorably linked; WTO is the only international organization which have the effective power to enforce its regulation; WTO has a court used to fix contentious issues between states;WTO exists, it does not necessitate creating a new organization through random of a new multilateral treaty. The global tax war needs a global answer. The way will be hard and long but it is the only mean to preserve the society in from of its risks of implosion. 


\section{Literature}

1. ALARIE, B., K. DATT, SAYER A., and $\mathrm{G}$ WEEKS. "Advance tax rulings in perspectives: a critical and comparative analysis." New Zeland Journal of taxation law and policy, December 2014: 362-389.

2. ALET, C. "La démocratie minée par les conflits d'intérêts. "Alternatives économiques, Mars 28, 2017.

3. ALTSHULER, R., and H. GRUBERT. "Repatriation taxes, repatriation strategies and multinational financial policy." Journal of Public Economics , 2003: 73-107.

4. ARMSTRONG, MA. "The potitila economy of international transfer pricing 1945-1994: state, capital \& decomposition of class." Critical perspectives on accounting, 1998: 111-126.

5. AUMANN, RJ., and M KURZ. "Power and taxes." Econometrica, July 1977: 11371161.

6. BANKMAN, J. "The tax shelter problem." National tax journal, 2004: 925-936.

7. BARILARI, A. Le consentement à l'impôt. Paris: Presse Universitaire de Science Po, 2000.

8. "Le consentement à l'impôt, fragile mais indispensable aporie." Regards croisés sur l'économie, Janvier 2007: 27-34.

9. BELZ, LC. "Federal tax rulings: procedures and policies." Vand L Review, 1967-68: 87-90.

10. BOYRIE, ME de, SJ PARK, and J. ZDANOWICZ. "Estimating the magnitude of capital flight due to abnormal pricing in international trade. The Russia-USA case." Accounting Forum, 2005: 249-270.

11. BOZIO, A., R. DAUVERGNE, B. FABRE, J. GOUPILLE, and O. MESLIN. Fiscalité et redistribution en France 19972012. Mars, Institut des politiques publiques, Paris: WWW.ipp.eu, 2012.

12. BRASHER, H, and D LOWERY. "The corporate context of lobbying activity." Business and Politics 8/1, 2006: 1.

13. BRENNAN, G., and JM. BUCHANAN. The power to tax. Analytic foundation of a fiscal constitution. Cambridge University Press, 1980.
14. BRUSCO S, COLOMBO L, GALMARINIU.

"Tax differentiation, lobbying and welfare." Social Choise \& Wefare, 2014: 977-1006.

15. CAILLÉ, A. "Quels fondements pour une fiscalité équitable?" Alternatives Économiques, Juil/Aout/Sept. 2010: 21-27.

16. CAILLON, M., P. LASCOUMES, and Y. BARTHES. Agir dans un monde incertain. Paris: Seuil, Ed. Point, Essais, 2014.

17. CHAVAGNEUX, C. "Comment le Royaume-Uni devient un paris fiscal." Alternatives Economiques, Mars 2011.

18. CHIRINKO, RS, and DJ WILSON. "Can lower tax rate be bought? Business rent-seeking and tax competition among US Staes." National Tax Journal, December 2010: 967-994.

19. CLERC, D. "Fiscalité et équité: proposition pour un débat." Alternatives Économiques, Juil/Aout/Sept. 2010: 7-20.

20. COASE, RH. La firme, le marché et le droit (1988). Paris: Diderot Editeur, Arts \& Sciences , 1997.

21. COBHAM, A. Tax evasion, tax avoidance and development finance. Oxford: Working Paper $N^{\circ} 129$, Oxford University, 2005.

22. COIN, R., P DURAND, and JP. LIEB. "Le rescrit fiscal." Cahier de droit de l'entreprise, 10-12 2010: 9-19.

23. COLLIARD, JE, and C MONTIALOUX. "Une brève histoire de l'impôt." Regards croisés sur l'économie, 2007: 56-65.

24. CROUY-CHANEL, E. de. "Le consentement à l'impôt." Pouvoirs, 2014: 5-14.

CUTUJAR, C., and P. DIENER. La société écran. Essai sur sa notion et son régime juridique. Paris: LGDJ, 1998.

25. DAVIS, A., D. GUENTHER, L. KRULC, and BM WILLIAMS. "Do socially responsible firms pay more taxes ?" The accounting review, 2016: 47-68.

26. DELALANDE, N. Les grandes batailles de l'impôt. Consentement et résistances de 1789 à nos jours. Paris: Seuil, 2001.

27. DELSOL, JP. "Le vent des subventions et de la corruption." Institut de Recherches 
Economiques et financières. Octobre 19, 2014. http://fr.irefeurope.org/Le-vent-dessubventions-et-de-la-corruption,a3129.

28. L'injustice fiscale ou l'abus de bien commun. Paris: Desclée de Brouwer, 2016.

29. DESAI, MA. "The divergence between book income and tax income." Tax policy and the economy, January 2003: 169-206.

30. DHARMAPALA, D, and JR jr. HINES. Which countries become tax havens? 12802, National Bureau of Economic Research, NBER Working paper series, 2006.

31. DILLER, M., P. KORTEBUSCH, G SCHNEIDERG, and C. SURETH-SLOAN. "Born or bane? Avance tax tuling as a mesure tomitigate tax uncertainty and foster investissement." European Accounting Review, 2016 йил 26-May: https://papers. ssrn.com/sol3/papers 2.cfm? abstract $i d=2442749$.

32. DOERNBERG, RL. International taxation. Edited by In a nutshell. Saint Paul Minesota: West Group, 2001.

33. DOWELL, S. A history of taxation and taxes in England from the earliest times to the year 1885. Vols. Volumes 1-4. Routledge, 1965.

34. DREZET, V. Un impôt juste pour une société juste. Paris: Ed. Syllepse, 2011.

35. DUMONT, AF. "Les millionnaires étrangers avec un mini-impôt unique." www.mariane.net. 2017 йил 12-mars. https://www.marianne.net/economie/ comment-l-italie-compte-draguer-lesmillionnaires-etrangers-avec-un-miniimpot-unique?utm_source $=$ Facebook\&utm $m$ e d i u $m=S$ o c i a $l$ \& u $t$ m campaign $=$ Echobox\#link time $=1489316261$. 36. EDEN, L., and RT. KUDRLE. "Tax heavens: renegade states in the international tax regime?" Law \& Polocy, 2005: 100-127. 37. FAJARDO, T. "Soft law." Oxford bibliographies. January 30, 2014. http:// oxfordbibliographies.com/view/document/ obo-9780199796953/obo-97801997969530040.xml.

38. FITZERALD, SF. La fêlure. Paris: Gallimard, 1963.

39. FOUMDJEM, C. Blanchiement des capitaux et fraude fiscale. Paris: l'Harmattan, 2011.
40. FREEDMAN, J. Beyond Boundaries. Developing approaches to tax avoidance and tax risk management. Oxford, UK: Oxford University. Center for business taxation, 2008.

41. FRIEDMAN, M. "The responsability of Business is to increase its profit." New York Times Magazine, September 1970.

42. GÉNÉREUX, J. La dissociété. Vol. $2^{\circ} \mathrm{Ed}$. Paris: Seuil, Collection Essais, 2008.

43. GAFREY, J. "Prélèvements obligatoires et choix de société." Alternatives économiques, Février 2004.

44. GOLLA, M. "Les étranges activités d'EDF dans les paradis fiscaux." Le Figaro, Décembre 2014.

45. HINES, JR. jr, and RG. HUBBARD. "Coming home to America: dividend repatriation by US multinationals." In Taxation in the global economy, by A. RAZIN and J. SLEMROD, 161-208. Chicago University Press, 1990.

46. JAMES, S., and I. WALLSCHUTZKY. "The design of an appropriate system of tax rulings." Revenue LJ, 1995: 175-192.

47. JAMESON, M. A practical guide to creative accounting. Kogan Page, 1988.

48. JONES, C., and Y. TEMOURI. "The determinants if tax haven FDI." Journal of world Business, 2016: 237-250.

49. JONES, M. Creative accounting, fraud and international accounting scandals. London: John Wiley \& Sons, 2010.

50. KERZNER, DS., and DW. CHODIKOFF. International tax evasion in the global information age. Palgrave Macmillan, 2016.

51. LASSERRE CAPDEVILLE, $J$. Le secret bancaire. Approches nationale et internationale. Paris: Revue Banque Edition, 2015.

52. LECAUSIN, N., JP. DELSOL, and E MARTIN. Anti-Piketty. Vive le capital au $X X I^{\circ}$ siècle. Paris: Ed. du Libre-Echange, 2015.

53. LIGNEREUX. Le principe de territorialité del'impôt sur les sociétés. Rapport particulier, Paris: Conseil D'Etat, 2016.

54. LOGUE, KD. "Optimal tax compliance and penalties when law is uncertain." VA Tax Review, 2007: 241 s. 
55. MALGORE, A. Montages juridiques et habileté fiscale. Paris: Gualino, 2016.

56. MANZON, GB., and GA PLESKO. "The relation between financial and tax reporting measure of income." Working paper, MIT Sloan School of Management, 2001.

57. MARA, ER. "Determinants of tax havens." Procedia Economics and Finance, 2015: 1638-1646.

58. MARTIN, E. "L'impôt sur les entreprises: injuste et ineficace." Institut de Recherches Economiques et Fiscales. Juillet 5, 2016. http://fr.irefeurope.org/4125.

59. MARTINEZ, JC, and Alii. L'impôt sur le revenu en question. Paris: Litec, 1989.

60. MEADE JA, LI S. "Strategic corporate tax lobbying." The Journal of American Taxation Association, 2015: 23-48.

61. MELOT, N. Territorialité et mondialité de l'impôt. Vol. 36. Paris: Dalloz, Nouvelle bibliothèque des thèses, 2004.

62. MIHU, S. "Tax havens and the money laudering phenomenon." Economics, Management and financial market, 2012: 151-176.

63. MURPHY, B. "When big firms of the web escape taxes." Edited by C, Cited In DUHIGG and KOCIENIEWSKI D. New York Times, April 2012.

64. MURPHY, R. "Tax and the universal declaration of human rights." www. taxresearch.org.uk/Blog/2014/02/14/taxthe-universal-declaration-of-human-rights/, Febuary 2014.

65. NÉEL, B. "Le secret bancaire face aux exigences fiscale et douanières." Revue Française de Finances Publiques 72 (2000).

OECD. "Addressing base erosion and profit shifting. " 2013.

66. OECD. "Améliorer l'accès aux renseignements bancaires à des fins fiscales." Rapport d'étape, 2007.

67. OECD. "BEPS 2015 final reports." 2015. OECD. BEPS project explanatory statements. http://www.keepeek.com/Digital-AssetManagement/oecd/taxation/beps-projectexplanatory-statement_9789264263437-en\#. WLPXyX8kQfI, 2015.

68. OECD. Corporate tax incentive for foreign direct investment. http://www. keepeek.com/Digital-Asset-Management/ oecd/taxation/corporate-tax-incentives-forforeign-direct-investment_9789264188402en\#.WLPWNX8kQfI, 2001.

69. OECD. Harful tax competition. A global issue. $\quad h t t p: / / w w w . k e e p e e k . c o m / D i g i t a l-$ Asset-Management/oecd/taxation/harmfultax-competition_9789264162945-en\#. WLPWkH8kQfI, 1998.

70. OECD. Preventing the granting of treaty benefits in inapropriate circumstances. Final report, OECD/G20 Base erosion and profit shifting project, 2015.

71. OECD. Subsidy reform and sustainable development. Political economy aspects. Sustanable development studies, 2007.

72. Transfer pricing and multinational enterprises . 1979.

73. Transfer pricing guidelines for multinational enterprises and tax administration. 2001.

74. OECD, R. FORD, and W. SUYKER. "Industrial subsidies in the OECD economies." Working paper, Department of economics and statistics- Growth studies division, 1990.

75. OST, F. Le temps du droit. Odile Jacob, 1999.

76. OXFAM. "Les 8 personnes les plus riches du monde possèdent autant que les 3,6 milliards les plus pauvres." L'express, Janvier 2017.

77. PALAN, R., R. MARPHY, and $C$. CHAVA GNEUX. Tax haves: how globalization really works. NY: Cornwell University Press, 2009.

78. PEILLON, V. Les milliards noirs $d u$ blanchiement. Paris: Hachette, 2004.

79. PERROT, E. "Les paradis fiscaux à l'ombre de la morale." Problèmes économiques, Septembre 2016: 52-57.

80. PICCIOTTO. "How tax havens helped create the crisis." Financial Time, May 5, 2009.

81. PIKETTY, T. Le capital au XXI $I^{\circ}$ siècle. Paris: Seuil, Les livres du nouveau monde, 2013.

82. QUAGHEBEUR, M. "Advance tax rulings in Belgium." Tax notes international, january 8, 2007: 53-55.

83. RADELLI, CM. "The code of conduct 
against tax competition: open method of coordination in disguise ?" Public Administration, 2003: 513-531.

84. REBELL, MA. "Fiscal equity litigation and the democratic imperative." Journal of education finance 24, no. 1 (Summer 1998): 23-50.

85. RENOU, F. "Des groupes dont le chiffre d'affaires dépasse des PIB." www. journaldunet.com, April 2009.

86. RICHTER, BK, K SAMPHANTHARAK, and JF TIMMONS. "Lobbying and taxes." American Journal of Political Science 53/4, 2009: 893-908.

87. ROMANO, C. Advance tax rulings and principle of law. Amsterdam: International Bureau of Fiscal Documentation, Publication $B V, 2002$.

88. ROUGÉ, JF. "Droit fiscal international." Document de cours M2 (190 p.). Inédit, 2016. 89. ROUGÉ, JF, and B. CHOPOV. "Hypercompetition and fiscal attactiveness." Economics, December 2016: 75-93.

90. ROUGÉ, JF. "Droit des affaires internationales. La compétition entre normes." Cours, M2 Affaires internationales. Angers: Université d'Angers, 2013. 185.

91. RUGMAN, A., EDEN, L. Multinationals and transfer pricing. London: Croom Helm, 1985.
92. SCOLARO, D. "Tax ruling: Opinion or law? The need for an independant rulemaker." Revenue law journal, 2006: 109-140. 93. SCOTCHMER, S., and J. SLEMROD. "Randomness in tax enforcement." Journal of Public Ecommics, 1989: 17 s.

94. SIKKA, P., and H WILLMOT. "The dark side of transfer pricing: its role in tax avoidance and wealth retentiveness. " Critical perspectives on accounting, April 2010: 342356.

95. SIMONNOT, P. 39 leçons d'économie contemporaine. Paris: Gallimard, Folio, Actuel, 1998.

96. STIGLITZ, JE. Quand le capitalisme perd la tête paris: Fayad, Livre de Poche, 2003.

97. STIGLITZ, JE. La grande désillusion. Paris: Fayard, Livre de poche, 2003.

-. Making globalization work. London: Pinguin Books, 2006.

98. TIROLE, J. Economie du bien commun. Paris: Presse Universitaire de France, 2016. 99. UNCTAD. "World Investment Report, global value chain: investment and trade for development." 2013.

Zero tolerance needed against tax secrecy. Press release (November 16, 2016).

100. ZUCMAN, G. La richesse cachée des nations. Enquête sur les paradis fiscaux. Seuil; La république des idées, 2013. 